\title{
Study on the Relationship between Supply and Demand of Talent Cultivation of Logistics Major in Higher Vocational Colleges
}

\author{
Leijie Ren \\ School of economics and management, Jiangsu Maritime Institute, Nanjing, Jiangsu, 211170, China
}

Keywords: logistics talents, Higher vocational colleges, Demand.

\begin{abstract}
The shortage of talents has seriously restricted the improvement of the overall level of logistics industry in our country. In particular, a large number of employees are far behind the international advanced level in terms of concepts, modes of thinking, knowledge structure and innovation ability, which directly affects the pace of development of logistics industry in our country. This paper has analyzed the current demand situation of logistics talents, forecast the demand situation of logistics talents in Jiangsu in the next five years, and further analyzed the causes of the dislocation of the supply and demand relationship of logistics talents, hoping to provide some help and suggestions for the development of logistics industry.
\end{abstract}

\section{Introduction}

High quality talents are the key factor of the development of modern logistics industry. However, at present the talents of logistics industry are extremely lacked. Data shows that logistics talents are one of the 12 types of talents in short supply in China ${ }^{[1]}$. Logistics education of higher vocational colleges started later in our country, and the cultivation of logistics talents by higher vocational colleges is far from satisfying the needs of enterprises. During the 13th five-year plan period, China's logistics industry needs about 1.3 million new employees every year, while at present, the annual number of graduates of logistics major in vocational colleges is about 400,000 to 500,000 , which is far from enough to meet the needs of first-line logistics skilled talents. The shortage of talents seriously restricts the development of overall level of logistics industry and directly affects the pace of development of logistics industry in China.

\section{The demand status of logistics talents in China}

\subsection{Research on the demand of logistics talents in different regions}

With the rapid development of logistics industry, the demand of local logistics enterprises for logistics talents is increasing day by day. Next, the author will analyze the demand status of logistics talents from the perspective of different regions.

\subsubsection{Southeast coastal area}

The economic zone of Yangtze river delta and the economic zone of pearl river delta are the two most powerful economic regions in China at present. The pearl river delta region is the earliest region of China's logistics industry. The pearl river delta region is the earliest region of logistics industry in China. The Yangtze river delta region has the largest comprehensive trading port in China -Shanghai port, with a throughput of 443 million tons per year. In recent 10 years, the logistics industry has been developing rapidly. These two regions have obvious regional advantages and developed transportation. They are important transportation hubs in the coastal belt of southeast China. They have a large number of logistics, production and manufacturing enterprises, as well as several large international airports and numerous large ports. They have large logistics business and they are the main area of logistics talents demand in China. According to incomplete statistics, the annual demand for logistics talents in Shanghai, Zhejiang, Jiangsu and other provinces amounts to 
2.12 million people. As the supply and demand relationship of logistics professionals is reversed at present, there is an extreme shortage of logistics talents, which delays the development pace of logistics industry in these regions.

\subsubsection{Central and western regions}

The logistics industry in the central and western regions started relatively late, and there is a big gap between them and the southeast coastal regions. This is mainly reflected in the fact that the number of logistics enterprises is far less than the southeast coastal region, the transportation industry is less developed than the southeast coastal region, the number of large airports and ports is very small. Therefore, the logistics enterprises in the central and western regions are mainly engaged in the transportation and storage industry. From the perspective of the demand for talents, due to the different position settings, the logistics enterprises in the central and western regions have relatively low requirements on the ability of logistics talents, and the threshold setting is lower than that in the southeast coastal regions.

\subsection{Research on the demand of logistics talents of different levels}

Modern logistics industry is an export-oriented and value-added service industry that combines the characteristics of knowledge intensive and technology intensive, capital intensive and labor intensive, and involves a wide range of fields ${ }^{[4]}$. From the current situation of logistics industry, two types of the talents are needed by logistics industry, one is technical operation logistics talents, the other is management logistics talents.

\subsubsection{Technical operational logistics talents}

The logistics industry in China late develops later compared with western countries, although it has caught up with western countries in terms of hardware, due to the education system, there are still few people who truly understand the concept of logistics and have complete logistics operation skills. With the continuous acceleration of modernization process, the development of logistics industry is also on the rise, the market demand for this kind of talents is increasing, and the gap of this kind of talents is also increasing.

\subsubsection{Management logistics talents}

Management is the foundation to the realization of the development goal of the logistics industry, and the requirements of management for management personnel are to have the latest logistics management concepts and mature management means, while China's logistics industry is most in short of such talents.

\section{Prediction of the demand of logistics talents in the logistics industry (Taking jiangsu as an example)}

Based on the data of Jiangsu statistical yearbook, we forecast the demand of logistics talents for enterprises in the logistics industry by using time series method and unary linear regression method.

Table 1. GDP of related industries in Jiangsu Province from 2011 to 2015 (GOP, same as below)

\begin{tabular}{|c|c|c|c|}
\hline Year & $\begin{array}{c}\text { GDP(hundred } \\
\text { million yuan) }\end{array}$ & $\begin{array}{c}\text { Total output value of logistics } \\
\text { enterprises(hundred million yuan) }\end{array}$ & GDP per capita(yuan) \\
\hline 2011 & 49110.27 & 2127.93 & 62290 \\
\hline 2012 & 54058.22 & 2352.40 & 68347 \\
\hline 2013 & 59753.37 & 2425.11 & 75164 \\
\hline 2014 & 65088.32 & 2591.15 & 81874 \\
\hline 2015 & 70116.38 & 2705.44 & 87995 \\
\hline
\end{tabular}

Table 2. The number of employees of logistics enterprises in Jiangsu Province from 2011 to 2015 


\begin{tabular}{|c|c|}
\hline Year & $\begin{array}{c}\text { Number of employees of logistics enterprises } \\
\text { (ten thousand people) }\end{array}$ \\
\hline 2011 & 79.77 \\
\hline 2012 & 85.00 \\
\hline 2013 & 86.74 \\
\hline 2014 & 93.29 \\
\hline 2015 & 110.24 \\
\hline
\end{tabular}

It can be seen that GDP is in proportion to the gross product of logistics enterprises, and the number of employees of logistics enterprises is also in proportion to the gross product of logistics enterprises.

Among the total cost composition of logistics activities, the ration of storage cost is about $60 \%$, while the transportation cost is about $20 \%$ to $30 \%$. The change of total cost of the storage cost and transportation cost represents the change of the whole logistics cost. As the total output value, GDP and the number of logistics employees in the logistics industry show a positive correlation, we can use the change of GDP of Jiangsu province to forecast the change of demand of logistics enterprise for logistics talents in Jiangsu Province.

\subsection{Forecast of Jiangsu GDP}

The data in table 2 shows that the GDP of Jiangsu Province grew along with the time series from 2011 to 2015. Therefore, we can use the time series method to forecast the GDP of Jiangsu Province from 2018 to 2022.

The prediction model is established by referring to the data in table 2 :

$$
\mathrm{Y}=c+d t
$$

In which, $\mathrm{t}$ is the number of time series, $\mathrm{c}$ and $\mathrm{d}$ are parameters

The second moving average method is adopted to assume that the first moving average of GDP is $\mathrm{N}_{\mathrm{t}}^{1}$, the second moving average is $\mathrm{N}_{\mathrm{t}}^{2}$, and the average time distance $\mathrm{n}$ is set as 3 , and the following formula is obtained:

$$
\begin{gathered}
c=2 N_{t}^{1}-N_{t}^{2} \\
d=N_{t}^{1}-N_{t}^{2}
\end{gathered}
$$

Next, the value of $\mathrm{N}_{\mathrm{t}}^{1}$ and $\mathrm{N}_{\mathrm{t}}^{2}$ is solved:

Assuming that the GDP of 2011-2015 is respectively $\mathrm{S}_{1}, \mathrm{~S}_{2}, \mathrm{~S}_{3}, \mathrm{~S}_{4}$ and $\mathrm{S}_{5}$, the following formula can be obtained:

$$
\begin{aligned}
& \mathrm{N}_{\mathrm{t}}^{1}(03)=\frac{\mathrm{S}_{1}+\mathrm{S}_{2}+\mathrm{S}_{3}}{3} \\
& \mathrm{~N}_{\mathrm{t}}^{1}(04)=\frac{\mathrm{S}_{2}+\mathrm{S}_{3}+\mathrm{S}_{4}}{3} \\
& \mathrm{~N}_{\mathrm{t}}^{1}(05)=\frac{\mathrm{S}_{3}+\mathrm{S}_{4}+\mathrm{S}_{5}}{3}
\end{aligned}
$$

Then the following formula can be obtained by doing the second moving:

$$
\mathrm{N}_{\mathrm{t}}^{2}(05)=\frac{\mathrm{N}_{\mathrm{t}}^{1}(03)+\mathrm{N}_{\mathrm{t}}^{1}(04)+\mathrm{N}_{\mathrm{t}}^{1}(05)}{3}
$$

Take the GDP data of 2011-2015 from table 3-2 into the above formula, and by calculation, we give the GDP forecast model of Jiangsu Province from 2018 to 2022:

$$
\mathrm{Y}_{\mathrm{t}}=70329.84+5343.82 \mathrm{t}, \mathrm{t}=\text { predicted year-2015 }
$$


The GDP of Jiangsu Province from 2018 to 2022 is as follows:

Table 3. Forecast table of total GDP of Jiangsu Province from 2018 to 2022

\begin{tabular}{|c|c|}
\hline Year & GDP(hundred million yuan) \\
\hline 2018 & 86361.30 \\
\hline 2019 & 91705.12 \\
\hline 2020 & 97048.94 \\
\hline 2021 & 102392.76 \\
\hline 2022 & 107736.58 \\
\hline
\end{tabular}

\subsection{The relationship between GDP of Jiangsu Province and total output value of logistics} enterprises

Based on the above analysis, we get a conclusion that the total output value of logistics enterprises is in proportion to GDP, that is, the increase of GDP is bound to bring the increase of total output of logistics enterprises. Set $\mathrm{s}$ as the GDP of Jiangsu Province and $\mathrm{x}$ as the total output value of logistics enterprises, and calculate the correlation between them by the following formula:

$$
r_{s x}=\frac{\sum_{i=1}^{n}\left(s_{i}-\bar{s}\right)\left(x_{i}-\bar{x}\right)}{\sqrt{\sum_{i=1}^{n}\left(s_{i}-\bar{s}\right)^{2}} \sqrt{\sum_{i=1}^{n}\left(x_{i}-\bar{x}\right)^{2}}}
$$

Based on the data in table 2, the following results can be obtained through calculation:

$$
\mathrm{r}_{\mathrm{SX}}=\frac{7377682.38}{\sqrt{281481984.63 \sqrt{198587.05}}} \approx 0.9868
$$

The correlation coefficient is 0.9868 which shows that the total output value of logistics enterprises in Jiangsu Province is highly correlated with GDP and has a linear relationship. Therefore, the unary linear regression equation can be used to predict the total output value of logistics enterprises in Jiangsu Province from 2018 to 2022. The specific model is as follows:

$\mathrm{x}=\mathrm{a}+\mathrm{bs}$, $\mathrm{a}, \mathrm{b}$ are regression parameters, in which

$$
\begin{gathered}
\mathrm{b}=\frac{\sum \mathrm{sx}-\frac{\sum \mathrm{s} \sum \mathrm{x}}{\mathrm{n}}}{\sum \mathrm{s}^{2}-\frac{\left(\sum \mathrm{s}\right)^{2}}{\mathrm{n}}} \\
\mathrm{a}=\overline{\mathrm{x}}-\mathrm{b} \overline{\mathrm{s}}
\end{gathered}
$$

By calculation, we get the total output value forecast table of logistics enterprises in Jiangsu Province from 2018 to 2022.

Table 4. 2018-2022 total output value forecast table of logistics enterprise in Jiangsu Province

\begin{tabular}{|c|c|}
\hline Year & $\begin{array}{c}\text { Total output value of logistics enterprises } \\
\text { (hundred million yuan) }\end{array}$ \\
\hline 2018 & 3291.54 \\
\hline 2019 & 3430.48 \\
\hline 2020 & 3569.42 \\
\hline 2021 & 3708.36 \\
\hline 2022 & 3847.30 \\
\hline
\end{tabular}




\subsection{The relationship model between the total output value and the number of employees of logistics enterprises in Jiangsu}

By analyzing the data in table 2 and table 3, we can see that the increase of the total output value of logistics enterprises in Jiangsu Province from 2011 to 2015 is bound to bring the increase of the number of employees in the logistics enterprises. In addition, through calculation, the correlation coefficient of the two is 0.99 which can determine that there is a linear relationship between them. Therefore, we use the unary linear regression equation to predict the number of employees in logistics enterprises of Jiangsu from 2018 to 2022. The total output value of logistics enterprise is s, the number of employees of logistics enterprise is $\mathrm{x}$, and the regression model is as follows:

$$
\mathrm{x}=-26.06+0.048 \mathrm{~s}
$$

The above model shows that for every 100 million RMB increase in the total output value of logistics enterprises in jiangsu province, the number of employees of logistics enterprises will increase by 260 .

The data in table 4 are substituted into the above formula to calculate the number of employees of logistics enterprises in Jiangsu each year from 2018 to 2022.

Table 5. prediction table of the number of employees of logistics enterprises in Jiangsu from 2018 to 2022

\begin{tabular}{|c|c|}
\hline Year & $\begin{array}{c}\text { Number of employees of logistics enterprises } \\
\text { (ten thousand people) }\end{array}$ \\
\hline 2018 & 131.93 \\
\hline 2019 & 138.60 \\
\hline 2020 & 145.27 \\
\hline 2021 & 151.94 \\
\hline 2022 & 158.61 \\
\hline
\end{tabular}

By 2022, the number of employees of logistics enterprises in Jiangsu will exceed 1,586,100.

Through data collection, we conclude that the demand of logistics talents in Jiangsu logistics enterprises accounts for about $63 \%$ of the total employees. Through calculation, we forecast that by 2022, the number of logistics talents of production enterprises in Jiangsu Province will reach 999,200, with a net increase of 168,100 .

At the same time, based on the data, we get that the demand of logistics talents for higher vocational colleges in Jiangsu Province from 2018 to 2022 will be 779,800.

It can be seen that the demand of talents of logistics major of higher vocational in Jiangsu will be very large in the next five years, which also indicates that the cause of the relationship reverse of talent supply and demand in logistics market is not the lack of market demand.

\section{Supply status of talents of logistics major in higher vocational colleges}

According to the data of Mycos, the annual number of graduates of logistics management major of higher vocational colleges is 94,700 , and it is 473,800 in five years. It can be seen that this data is far lower than the demand of the logistics market for logistics talents of higher vocational colleges. Therefore, we are sure that graduates majoring in logistics in higher vocational colleges who have difficulty in finding jobs and facing the mismatch of major is not because supply exceeds demand.

\section{The reason of supply and demand dislocation of logistics major of higher vocational colleges}

We conducted a follow-up survey on 371 graduates from a vocational college in Jiangsu and the enterprises they work for. According to the survey data, enterprises are generally dissatisfied with the ability of graduates sent by vocational colleges. We can see that the quality of talents of logistics major cultivated by higher vocational colleges is relatively poor currently. 


\subsection{There is a serious lack of talents}

Based on the above data, through calculation, we predict that the total demand for logistics talents in China will exceed 2 million in the next five years. However, the number of college entrance exam candidates in some provinces has been in a downward trend since 2015. In addition, the enrollment scale of undergraduate colleges has not reduced, and the enrollment scale of higher vocational colleges has further reduced, leading to the reduction of the enrollment scale of logistics management majors. Although it is expected that the number of students majoring in logistics management will gradually recover in the next five years starting from 2018, the annual output of logistics talents in higher vocational colleges will hardly exceed 164,800, in five years it is 824,000, far lower than the 2 million as the total demand of logistics talents in five years, the supply quantity is seriously insufficient.

\subsection{The quality of cultivation cannot meet the needs of enterprises}

According to the survey data, the quality of graduates in higher vocational colleges can hardly meet the needs of enterprises and the development of the industry, including the following problems:

\subsubsection{Lack of professional theoretical knowledge and practical ability}

From the feedback of employers to graduates, they generally feel that the students lack professional theoretical knowledge and the competition for graduates is low. In addition, enterprises generally reflect that graduates have poor operational ability, some even do not know how to do, seriously restricting the development of talents.

\subsubsection{Lack of necessary basic qualities}

Through the research, we find that the quality of most graduates is not optimistic. Many graduates hold the idea of going on tolling the bell as long as one is a monk, lacking a sense of belonging to the enterprise and the career, without their own career planning, seeking stability in the work, drifting along, and do not strive to make progress, just want to lead their own lives.

\section{Summary}

Based on the above analysis, we can see that the fundamental reason of the reverse relationship of supply and demand of talents of logistics major in the current logistics market is that there are relatively big problems in the talent cultivation in higher vocational colleges, and the talents cultivated cannot meet the needs of enterprises. For higher vocational colleges, how to cultivate qualified talents of logistics major with high technical skills to promote comprehensive development of China's logistics industry is a long way to go.

\section{References}

[1] Yuzang, Tang. Research on improving post skills of talents of logistics enterprises, Capital University of Economics and Business, 2014(10):05.

[2] Kai, Zeng, Chuanjun, Ma, Lindu Zhao. SWOT analysis of developing modern logistics industry in Yangtze river delta and pearl river delta, Logistics technology, 2005(01):12-16.

[3] Ting, Luo, Linglu, Tian, etc. Investigation and analysis of logistics talent demand, Wuhu: Chinese logistics academic annual meeting, 2016.

[4] Dali, Jiang, Feng, Wang, Jianfang, Zhang, Huiyin, Wang. Industry logistics management, Beijing: China Petrochemical Press, 2004. 